\title{
Interaction of human Tamm-Horsfall glycoprotein with Bordetella pertussis toxin
}

\author{
Franco D. Menozzi, ${ }^{1}$ Anne-Sophie Debrie, ${ }^{1}$ Jean-Pierre Tissier, ${ }^{2}$ \\ Camille Locht, ${ }^{1}$ Kevin Pethe ${ }^{1}$ and Dominique Raze ${ }^{1}$
}

Author for correspondence: Franco D. Menozzi. Tel: +33 320871154. Fax: + 33320871158.
e-mail: franco.menozzi@pasteur-lille.fr

1 Institut Pasteur de Lille, INSERM U447, Mécanismes moléculaires de la pathogénie microbienne, 1 Rue du Professeur Calmette, 59019 Lille Cedex, France

2 Institut National de la Recherche Agronomique, Laboratoire de Génie des Procédés et Technologie Alimentaires, 369 Rue Jules Guesde, 59651 Villeneuve d'Ascq, France

\begin{abstract}
Tamm-Horsfall glycoprotein (THP), which is synthesized by renal tubular cells, is the most abundant protein in normal human urine. Although its physiological function remains unclear, it has been proposed that THP may act as a defence factor against urinary tract infections by inhibiting the binding of S- and P-fimbriated Escherichia coli to renal epithelial cells. Because THPrelated proteins are also found in the superficial layers of the oral mucosa, the authors investigated the ability of THP to interfere with the cytoadherence of pathogenic bacteria that colonize mucosal surfaces other than those of the urogenital tract. In this report, it is shown that THP binds to virulent Bordetella pertussis and reduces its adherence to both renal and pulmonary epithelial cells. This cytoadherence inhibitory effect was not observed with a B. pertussis mutant lacking the pertussis toxin (PTX) operon, and was dependent on the direct interaction of THP with the S2 subunit within the PTX B oligomer. The authors also show that the glycosylation moiety of THP is crucial for its binding to PTX. The THP-PTX interaction was exploited to develop an affinity chromatography method that allows a one-step purification of active PTX. These observations suggest that besides its anti-adherence activity, THP may also trap toxins produced by pathogenic bacteria that colonize mucosal surfaces.
\end{abstract}

Keywords: cytoadherence, purification, virulence

\section{INTRODUCTION}

Tamm-Horsfall glycoprotein (THP; $90 \mathrm{kDa}$ ) is the most abundant protein found in normal human urine and its daily excretion ranges from 20 to $200 \mathrm{mg}$ (Hunt et al., 1985; Tamm \& Horsfall, 1952). The carbohydrate moiety of THP is essentially composed of N-linked sugars, and accounts for $30 \%$ of the protein by weight (Easton et al., 2000; Hard et al., 1992). THP is synthesized by the renal tubular cells of the thick ascending limb of the loop of Henle (Bachmann et al., 1990), and it has been postulated that THP might be responsible for the water impermeability of this segment of the nephron (Kumar \& Muchmore, 1990). THP displays a marked tendency to form reticulated aggregates (Bjugn \& Flood, 1988), which has obvious

Abbreviations: $\mathrm{CHO}$, chinese hamster ovary; O-glycosidase, glycopeptide $\alpha$ - $N$-acetylgalactosaminidase; PTX, pertussis toxin; FHA, filamentous haemagglutinin; THP, Tamm-Horsfall glycoprotein. implications for urinary-cast formation (Worcester et al., 1988).

Although the physiological function of THP remains uncertain, several observations suggest that it could be involved in urothelial defences against infection; for example Orskov et al. (1980) showed that Escherichia coli with type I fimbriae are trapped by THP. The binding of THP to E. coli type I pili depends on the mannose content of THP (Kuriyama \& Silverblatt, 1986); more recently, in vitro cytoadherence assays showed that THP also inhibits the binding of S- and Pfimbriated E. coli to human renal tubular epithelial cells (Leeker et al., 1997). Additionally, THP may stimulate polymorphonuclear leukocytes in the course of an inflammatory response (Horton et al., 1990). Although THP distribution in humans is limited to the kidney, immunoreactive THP-related proteins have been detected at other mucosal surfaces of several vertebrates (Howie et al., 1993). These observations suggest that THP-like proteins could also be involved in the defence(s) against infectious agents at other mucosal sites, 
by impeding their cytoadherence. To test the capability of THP to reduce the epithelial adherence of nonuropathogenic bacteria, we investigated the interaction of THP with Bordetella pertussis, the aetiological agent of whooping cough, which colonizes the human upperrespiratory tract. In this study, we show that besides its anti-adherence activity, THP is also able to trap pertussis toxin (PTX).

\section{METHODS}

Bacterial strains and growth conditions. B. pertussis strains (Table 1) were grown on Bordet-Gengou agar (Bordet \& Gengou, 1906) supplemented with $20 \%$ (v/v) defibrinated sheep blood and containing either $100 \mu \mathrm{g}$ streptomycin $\mathrm{ml}^{-1}$ (Sigma) for strains BPSM, BPRA, BPGR4 and BPLOW, or $20 \mu \mathrm{g}$ ampicillin $\mathrm{ml}^{-1}$ (Sigma) for strains $\Delta \mathrm{S} 2$ and $\Delta \mathrm{S} 3$. Liquid cultures were performed as described previously (Menozzi et al., 1991), using modified Stainer \& Scholte (SS) medium containing $1 \mathrm{~g}$ (2,6-O-dimethyl)- $\beta$-cyclodextrin $\mathrm{l}^{-1}$ (Imaizumi et al., 1983) as well as the relevant antibiotics. For cytoadherence assays, $B$. pertussis cells grown for $48 \mathrm{~h}\left(37^{\circ} \mathrm{C}\right)$ on Bordet-Gengou agar were suspended to an $\mathrm{OD}_{600}$ of $0 \cdot 15$ in test tubes containing $2.5 \mathrm{ml} \mathrm{SS}$ medium supplemented with $65 \mu \mathrm{Ci}(2.40 \mathrm{MBq})$ L- $\left[{ }^{35} \mathrm{~S}\right]$ methionine + cysteine $\mathrm{ml}^{-1}$ (Expre${ }^{35} \mathrm{~S}^{35} \mathrm{~S}$ Protein Labelling Mix; $1175 \mathrm{Ci} \mathrm{mmol}^{-1}$; NEN). After $24 \mathrm{~h}$ growth at $37^{\circ} \mathrm{C}$ under agitation, the bacteria were washed three times with $10 \mathrm{ml}$ PBS $\left(20 \mathrm{mM} \mathrm{Na} \mathrm{Na}_{2} \mathrm{HPO}_{4}\right.$;

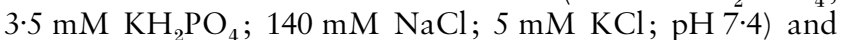
resuspended in RPMI 1640 (Gibco) without serum to an $\mathrm{OD}_{540}$ of $0 \cdot 12$, corresponding to approximately $1 \cdot 2 \times 10^{8}$ c.f.u. $\mathrm{ml}^{-1}$.

Protein purification. For the purification of human THP, a urine sample was collected over a $24 \mathrm{~h}$ period from a healthy adult male and frozen at $-30{ }^{\circ} \mathrm{C}$. After thawing at room temperature, the precipitate was collected by centrifugation at $20000 \mathrm{~g}$ for $20 \mathrm{~min}$ at $4{ }^{\circ} \mathrm{C}$. The pellet was resuspended in $40 \mathrm{ml}$ distilled water adjusted to $\mathrm{pH} 8.8$ with $1 \mathrm{M} \mathrm{NaOH}$ and

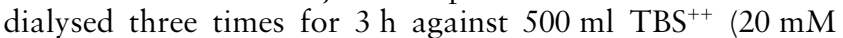
Tris/HCl, pH 7.5; $1 \mathrm{mM} \mathrm{MgCl} ; 1 \mathrm{mM} \mathrm{CaCl}$; $1 \mathrm{mM}$ $\mathrm{MnCl}_{2}$ ). The solution was then chromatographed at room temperature, using a $1 \mathrm{~cm}$ diameter glass column packed with $10 \mathrm{ml}$ Concanavalin A Sepharose (Pharmacia) equilibrated in $\mathrm{TBS}^{++}$. After sample loading and washing with $\mathrm{TBS}^{++}$, THP was eluted with $\mathrm{TBS}^{++}$containing $500 \mathrm{mM}$ methyl $\alpha$-Dmannopyranoside (Sigma). Purified THP was dialysed three times against $900 \mathrm{ml} \mathrm{PBS}$ and then stored at $-30^{\circ} \mathrm{C}$ until further use.
PTX was purified from B. pertussis BPSM culture supernatant using Affi-Gel Blue chromatography (Bio-Rad) followed by fetuin-Sepharose (Sigma) affinity chromatography, as described by Sekura et al. (1983). Purified PTX was dialysed against PBS and stored in $500 \mu \mathrm{l}$ aliquots at $-30{ }^{\circ} \mathrm{C}$.

Production of antisera. Five hundred microlitres of purified PTX or THP antigen $\left[100 \mu \mathrm{g}(\mathrm{ml} \mathrm{PBS})^{-1}\right]$ were mixed with $500 \mu \mathrm{l}$ of a monophosphoryl lipid A solution (MPL + TDM Adjuvant System; Sigma) prepared according to the manufacturer's recommendations. BALB/c mice were immunized with $300 \mu$ of the antigen suspension in the following way. For each animal, $200 \mu \mathrm{l}$ of the antigen suspension was given intraperitoneally, followed by two subcutaneous injections of $50 \mu \mathrm{l}$ each. The animals were boosted the same way with the same amounts of antigen 4 and 6 weeks later; the antisera were collected 3 weeks after the last boost.

Enzymic deglycosylation of THP. Purified human THP at $5 \mathrm{mg} \mathrm{ml}^{-1}$ in PBS was treated for up to $15 \mathrm{~h}$ at $37^{\circ} \mathrm{C}$ with $0.5 \mathrm{U}$ $N$-glycosidase F (EC 3.5.1.52; Roche) per mg THP or with $1 \mathrm{mU}$ glycopeptide $\alpha$-N-acetylgalactosaminidase [O-glycosidase; EC 3.2.1.97; Roche] per mg THP.

Covalent coupling of THP to Sepharose. Native or deglycosylated human THP was covalently coupled to CNBractivated Sepharose 4B (Pharmacia) as follows. Three grams of $\mathrm{CNBr}$-activated Sepharose 4B was first washed with $50 \mathrm{ml}$ ice-cold $1 \mathrm{mM} \mathrm{HCl}$ followed by $150 \mathrm{ml}$ PBS. The gel was then mixed with $10 \mathrm{ml}$ of THP $\left(5 \mathrm{mg} \mathrm{m}^{-1}\right)$ in PBS and incubated for $5 \mathrm{~h}$ at room temperature. After blocking of the remaining active groups by incubation for $1 \mathrm{~h}$ at room temperature in $25 \mathrm{ml} 0 \cdot 2 \mathrm{M}$ glycine, $\mathrm{pH} 8 \cdot 0$, the THP-Sepharose gel was stored at $4{ }^{\circ} \mathrm{C}$ in PBS containing $20 \%(\mathrm{v} / \mathrm{v})$ ethanol. For both the native and the deglycosylated forms of human THP, coupling efficiencies were between 95 and $100 \%$.

Chromatography of $B$. pertussis culture supernatants onto THP-Sepharose. Late-exponential phase supernatants from $800 \mathrm{ml} \mathrm{B.} \mathrm{pertussis} \mathrm{cultures} \mathrm{were} \mathrm{collected} \mathrm{by} \mathrm{centrifugation} \mathrm{at}$ $10000 \mathrm{~g}$ for $15 \mathrm{~min}$ at $4{ }^{\circ} \mathrm{C}$ and were then loaded at $2 \mathrm{ml} \mathrm{min}{ }^{-1}$ onto $5 \mathrm{ml}$ PBS-equilibrated THP-Sepharose packed in a $1 \mathrm{~cm}$ diameter column. After extensive washing, retained material was step-wise eluted using successively PBS $+3 \mathrm{M} \mathrm{NaCl}$, PBS $+0.5 \mathrm{M}$ methyl $\alpha$-D-mannopyranoside, PBS $+3 \mathrm{M}$ urea and $\mathrm{PBS}+6 \mathrm{M}$ urea. Eluted material was collected in $1 \mathrm{ml}$ fractions and stored at $-30{ }^{\circ} \mathrm{C}$ until further use.

B. pertussis cytoadherence assays. Human pulmonary epithelial cells (A549; ATCC CCL-185) and canine kidney epithelial cells (MDCK; ATCC CCL-34) were cultured in $75 \mathrm{~cm}^{2}$ Roux flasks (Costar) using RPMI medium sup-

Table 1. B. pertussis strains used in this study

\begin{tabular}{|lll|}
\hline Strain & \multicolumn{1}{c|}{ Relevant features } & \multicolumn{1}{c|}{ Reference } \\
\hline BPSM & Streptomycin-resistant B. pertussis Tohama I derivative & Menozzi et al. (1994a) \\
BPRA & BPSM lacking the PTX structural gene & Antoine \& Locht (1990) \\
BPGR4 & BPSM lacking fhaB & Locht et al. (1992) \\
BPLOW & BPSM carrying a chromosomal deletion of bvgAS & Antoine et al. (2000) \\
$\Delta$ S2 & $\begin{array}{c}\text { Derivative of BPRA with an integrated } p t x \text { operon lacking } \\
\text { the S2 subunit gene without frame shift }\end{array}$ & $\begin{array}{c}\text { D. Raze and others } \\
\text { (unpublished) }\end{array}$ \\
& Derivative of BPRA with an integrated ptx operon lacking & D. Raze and others \\
& the S3 subunit gene without frame shift & (unpublished) \\
\hline
\end{tabular}


plemented with $50 \mu \mathrm{g}$ streptomycin $\mathrm{ml}^{-1}$ (Sigma), $2 \mathrm{mM} \mathrm{L-}$ glutamine (Gibco) and $10 \%(\mathrm{v} / \mathrm{v})$ heat-inactivated fetal bovine serum (Gibco). The day before the adherence assay, the wells of 24-well tissue culture trays (Nunc) were seeded with $2 \times 10^{5}$ exponentially growing epithelial cells resuspended in $2 \mathrm{ml}$ of serum-supplemented RPMI medium. Before the addition to each well of $500 \mu \mathrm{l}$ of RPMI medium containing $4 \times 10^{6}{ }^{35} \mathrm{~S}$-labelled $B$. pertussis cells, corresponding to an m.o.i. of 10 , the epithelial cells were washed twice with $1 \mathrm{ml}$ PBS. At the end of $2 \mathrm{~h}$ incubation at $37^{\circ} \mathrm{C}$, non-adherent bacteria were removed by three washes with $1 \mathrm{ml}$ PBS and the cells were lysed by adding $500 \mu \mathrm{l}$ distilled water containing $0 \cdot 1 \%(\mathrm{w} / \mathrm{v})$ SDS. The radioactivity associated with the cellular lysates was quantified using a liquid scintillation counter (model LS 6000SC; Beckman). Bacterial adherence was expressed as the percentage of radioactivity associated with the cell lysates relative to that present in the inoculum. The adherence assays were performed in quadruplicate and the results are expressed as the mean $\pm \mathrm{SD}$.

Flow cytometry analysis of the $B$. pertussis-THP interaction. Approximately $10^{8}$ exponentially growing $B$. pertussis cells were harvested by low-speed centrifugation and washed twice in $2 \mathrm{ml}$ PBS. Bacteria were then resuspended in $1 \mathrm{ml}$ PBS containing $100 \mu \mathrm{g}$ purified human THP and incubated for $30 \mathrm{~min}$ at room temperature. After three washes with PBS, the cells were incubated for $1 \mathrm{~h}$ at room temperature with mouseanti-human THP antiserum diluted 500-fold in PBS. The bacteria were then washed three times with PBS and incubated for $30 \mathrm{~min}$ at room temperature in $1 \mathrm{ml}$ of FITC-conjugated donkey-anti-mouse IgG (Jackson ImmunoResearch Laboratories) diluted 500-fold in PBS. After three final washes with PBS, the bacteria were fixed with $500 \mu \mathrm{l}$ of $4 \%$ paraformaldehyde. Cell-associated fluorescence (expressed as the percentage of FITC-labelled B. pertussis) was quantified by flow cytometry using an EPICS Elite cytometer (Coulter); fluorescence associated with bacteria that were not incubated with THP was used for background determination.

Scanning electron microscopy. B. pertussis BPSM grown for $48 \mathrm{~h}$ on Bordet-Gengou agar plates was scraped using an inoculating loop and carefully resuspended at a density of $10^{7}$ cells $\mathrm{ml}^{-1}$ in PBS or in PBS supplemented with $100 \mu \mathrm{g}$ THP ml $\mathrm{m}^{-1}$. The bacteria were then directly fixed for $5 \mathrm{~h}$ at room temperature in a $1.25 \%(\mathrm{v} / \mathrm{v})$ glutaraldehyde solution prepared in $100 \mathrm{mM}$ sodium cacodylate buffer, $\mathrm{pH} 7 \cdot 0$. Aliquots containing approximately $10^{6}$ cells were filtered through a $25 \mathrm{~mm}$ diameter $/ 0 \cdot 2 \mu \mathrm{m}$ porosity Anodisc (Whatman); the filters were then rinsed five times for $10 \mathrm{~min}$ in $25 \mathrm{ml}$ cacodylate buffer. Post-fixation was performed for $3 \mathrm{~h}$ in a $1 \%$ $\mathrm{OsO}_{4}$ solution prepared in cacodylate buffer, followed by five washes in ultrapure water. The samples underwent progressive dehydration by successive soaking in 50, 70, 95 and $100 \%$ ethanol. Soaking in isopentyl acetate was performed before critical-point drying in $\mathrm{CO}_{2}$, using an EMSDCOPE CPD 750 apparatus. The filters were then attached to large scanning-electron-microscopy stubs and coated with gold/ palladium by cathodic spreading in a Polaron E 5100 coater. Sample observation and microphotographs were done in a JEOL JSM35CF scanning electron microscope, operating at a voltage of $10 \mathrm{kV}$.

Other analytical procedures. Chinese hamster ovary (CHO) cells (CHO-K1; ATCC CRL-9618) were cultured in monolayers using RPMI 1640 medium containing $10 \%$ (v/v) fetal bovine serum. The clustering effect of PTX on CHO-K1 cells was monitored in flat-bottom microtitre plates (Dynatech Laboratories) as described by Hewlett et al. (1983), using purified PTX at concentrations ranging from $2 \mu \mathrm{g} \mathrm{m}{ }^{-1}$ to $1 \mathrm{ng} \mathrm{ml}^{-1}$.

SDS-PAGE was performed according to Laemmli (1970) by using a $4 \%$ stacking gel and a $15 \%$ separating gel. After electrophoresis, the gels were stained with Coomassie brilliant blue R-250 (Merck).

The transfer of proteins from SDS-polyacrylamide gels to nitrocellulose sheets (BA 85; Schleicher \& Schuell) was performed as described by Towbin et al. (1979). Immobilized PTX was probed with a murine-anti-PTX antiserum diluted 1000-fold and developed with alkaline phosphatase-linked goat-anti-mouse immunoglobulin G (ProtoBlot System; Promega).

Protein concentrations were determined with the bicinchoninic acid protein assay (Pierce), using BSA as a standard.

\section{RESULTS}

\section{THP inhibits the adherence of $B$. pertussis BPSM to MDCK cells}

To determine whether THP is able to inhibit the cytoadherence of pathogenic bacteria other than those infecting the urogenital tract, we studied the interaction of virulent B. pertussis BPSM with renal epithelial MDCK cells in the presence of THP at concentrations ranging from 0 to $20 \mu \mathrm{g} \mathrm{ml}^{-1}$. Using an m.o.i. of 10 bacteria per MDCK cell, as little as $10 \mu \mathrm{g}$ THP ml $\mathrm{ml}^{-1}$ reduced the binding of radiolabelled $B$. pertussis BPSM to MDCK cells by approximately $80 \%$ (data not shown). No further decrease in adherence was observed with THP concentrations of up to $100 \mu \mathrm{g} \mathrm{ml}^{-1}$ (data not shown). The observation that the THP-mediated inhibition of adherence was saturable suggests the presence of a specific THP ligand on the surface of $B$. pertussis BPSM.

\section{THP binding to virulent and avirulent $B$. pertussis}

To investigate whether the THP ligand is part of the general virulence regulon under the control of the BvgAS two-component system (Uhl \& Miller, 1995), we compared the binding of THP to virulent $B$. pertussis BPSM and to avirulent $B$. pertussis BPLOW, which carries a chromosomal deletion of the bvgAS operon. The binding of THP to $B$. pertussis BPLOW was reduced by approximately $40 \%$ compared to that of virulent $B$. pertussis BPSM, as evidenced by flow cytometry analysis (data not shown). This indicates that $b v g A S$-regulated virulence factors are involved in the interaction with THP.

\section{Involvement of PTX in the THP-mediated inhibition of $B$. pertussis adherence}

To determine whether any of the known virulence factors, such as filamentous haemagglutinin (FHA) and/or PTX, are involved in the THP-mediated inhibition of $B$. pertussis adherence, the adherence assay was carried out using BPSM derivatives lacking FHA or 


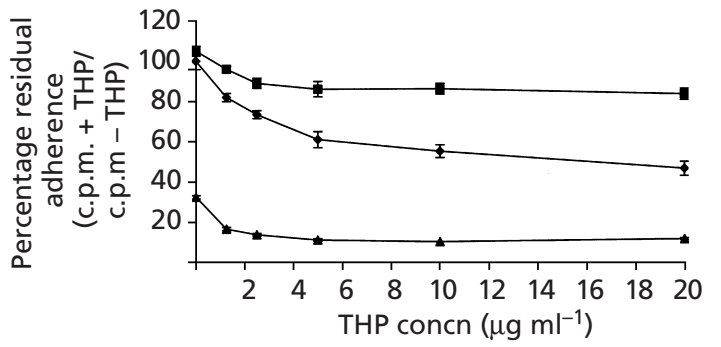

Fig. 1. Effect of increasing concentrations of THP on the adherence of $B$. pertussis BPSM $(\diamond), B$. pertussis BPRA $(\boldsymbol{\square})$ and B. pertussis BPGR4 ( $\boldsymbol{A}$ ) to A549 human type II pneumocytes. Metabolically labelled $B$. pertussis was incubated for $2 \mathrm{~h}$ with A549 cells using an m.o.i. of 10 . For each strain, the radioactivity associated with the eukaryotic cells was determined, and residual adherence was expressed as the percentage of radioactivity associated with the cell lysates (c.p.m. +THP) relative to that present in the inoculum (c.p.m. - THP). The data represent the means of quadruplicate experiments \pm SD.

PTX. As observed with MDCK cells, THP also induced a saturable and dose-dependent inhibition of B. pertussis BPSM adherence onto A549 pneumocytes (Fig. 1). However, this inhibition was less pronounced than that observed with MDCK cells, since it was limited to approximately $50 \%$ in the presence of $10 \mu \mathrm{g} \mathrm{THP} \mathrm{ml}^{-1}$. Although the adherence of $B$. pertussis BPGR4 (a strain lacking FHA) was reduced by approximately $70 \%$ compared to its parental $B$. pertussis BPSM strain, even in the absence of THP, $10 \mu \mathrm{g}$ THP ml ${ }^{-1}$ further reduced B. pertussis BPGR 4 adherence by an additional $50 \%$. This finding suggests that FHA is not involved in the THP-mediated inhibition of adherence. In contrast, the adherence of $B$. pertussis BPRA (a strain deficient for PTX), which is comparable to that of B. pertussis BPSM in the absence of THP, was less sensitive to THP, since $10 \mu \mathrm{g}$ THP ml ${ }^{-1}$ induced only a $15 \%$ reduction of adherence, suggesting that PTX is implicated in the $B$. pertussis-THP interaction.

\section{Direct interaction of THP with PTX}

THP-Sepharose 4B was used as an affinity chromatography matrix to analyse a $B$. pertussis BPSM culture supernatant containing secreted PTX, to determine whether PTX was able to interact directly with THP. After sample application followed by washing, material retained on the matrix was successively eluted with PBS containing $3 \mathrm{M} \mathrm{NaCl}, 0.5 \mathrm{M}$ methyl $\alpha$-D-mannopyranoside, $3 \mathrm{M}$ urea and finally $6 \mathrm{M}$ urea. As shown in Fig. 2 (a), only the PBS $+3 \mathrm{M}$ urea elution step yielded an elution peak, as monitored at $A_{280}$. SDS-PAGE analysis of the $1 \mathrm{ml}$ fractions of this peak revealed that it contained five protein bands, displaying an electrophoretic pattern typical of PTX (Sekura et al., 1983). Immunoblot analysis using anti-PTX antibodies confirmed that these bands corresponded to PTX (Fig. 3). Similar analyses using anti-FHA monoclonal antibodies failed to demonstrate the binding of FHA to THP-
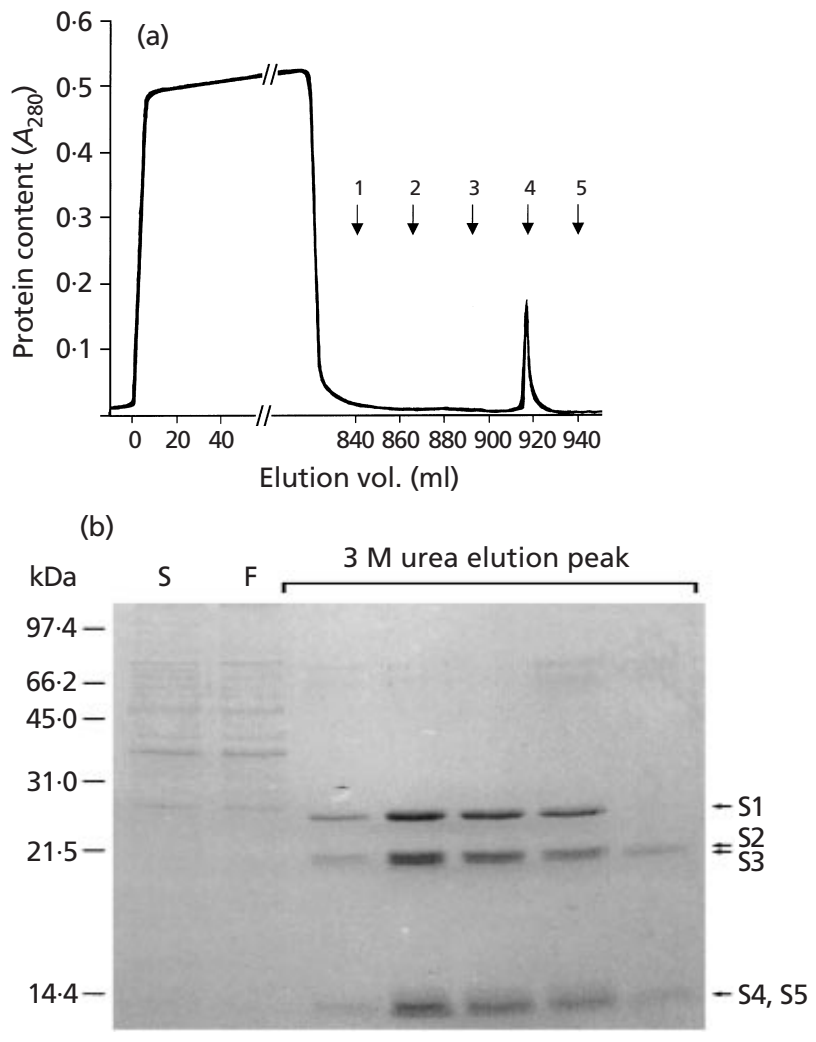

Fig. 2. (a) Chromatogram of $800 \mathrm{ml} \mathrm{B}$. pertussis BPSM culture supernatant on $5 \mathrm{ml}$ THP-Sepharose 4B equilibrated with PBS. After sample application followed by washing with PBS (arrow 1), the gel was eluted step-wise with $\mathrm{PBS}+3 \mathrm{M} \mathrm{NaCl}$ (arrow 2), PBS + 0.5 M methyl $\alpha$-D-mannopyranoside (arrow 3), PBS + $3 \mathrm{M}$ urea (arrow 4) and PBS $+6 \mathrm{M}$ urea (arrow 5). (b) SDS-PAGE analysis of the $B$. pertussis BPSM culture supernatant prior to chromatography (S), column flow-through (F) and $1 \mathrm{ml}$ fractions from the $3 \mathrm{M}$ urea elution peak presented in (a). S1-S5 represent the various subunits of the B oligomer of PTX.

Sepharose (data not shown). In the experimental conditions used, no PTX was detected by immunoblotting in the column flow-through, indicating that immobilized THP is a powerful ligand for PTX. Moreover, the THP-PTX interaction was very strong, since up to $5 \mathrm{M}$ $\mathrm{NaCl}$ did not elute PTX. Elution of PTX required the presence of $3 \mathrm{M}$ urea or $0 \cdot 1 \%$ SDS (data not shown). The THP-Sepharose was also quite stable, since no decrease in PTX purification yield was observed during repeated use of the affinity chromatographic matrix.

\section{PTX binds to THP via the S2 subunit of the B oligomer}

SDS-PAGE analysis of the tail fraction of the $3 \mathrm{M}$ urea elution peak showed the presence of, essentially, the S2-S5 subunits of the B oligomer of PTX with no detectable S1 subunit (Fig. 2b), suggesting that the THP-PTX interaction is mediated by this oligomer. Since the highly similar S2 and S3 subunits of the B oligomer are involved in the various binding activities of 


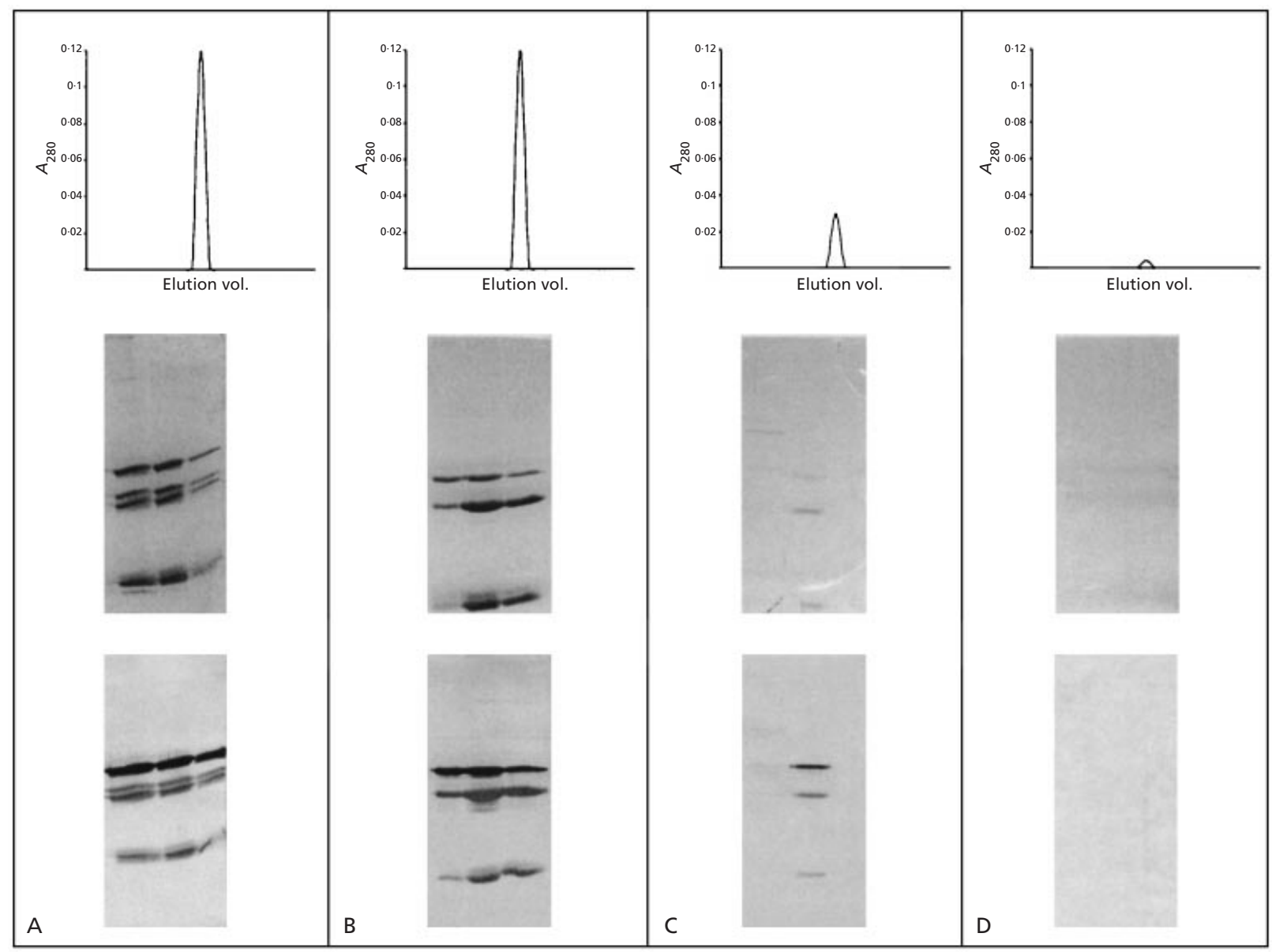

Fig. 3. Comparative analysis of the interaction of PTX, PTX $\Delta S 3$ and PTX $\Delta S 2$ with THP or with $N$-deglycosylated THP covalently bound to Sepharose. Samples $(800 \mathrm{ml})$ of the following culture supernatants were chromatographed on THPSepharose or on $\mathrm{N}$-deglycosylated THP-Sepharose and were then eluted. (A) B. pertussis BPSM (PTX) with THPSepharose; (B) B. pertussis $\Delta \mathrm{S} 3$ (PTX $\Delta \mathrm{S} 3$ ) with THP-Sepharose; (C) B. pertussis $\Delta \mathrm{S} 2$ (PTX $\Delta \mathrm{S} 2$ ) with THP-Sepharose; (D) B. pertussis BPSM with $N$-deglycosylated THP-Sepharose. The elution peaks with PBS $+3 \mathrm{M}$ urea are shown (top of each panel; protein content is shown as $A_{280}$ ), as well as their contents as analysed by SDS-PAGE (middle of each panel) and by immunoblotting with anti-PTX antibodies (bottom of each panel).

PTX (Lobet et al., 1993), we tested the THP-PTX interactions using PTX produced by $B$. pertussis mutants which were unable to produce the $\mathrm{S} 2$ or $\mathrm{S} 3$ subunit $(\Delta \mathrm{S} 2$ or $\Delta \mathrm{S} 3$ mutant, respectively). [These mutants do, however, produce a correctly assembled holotoxin, through replacement of the missing subunit by a second copy of the S3 or S2 subunit (D. Raze, F. D. Menozzi, R. Antoine, Y. Sato and C. Locht, unpublished)]. As shown in Fig. 3, after chromatography on THP-Sepharose, the elution peak of the culture supernatant of $B$. pertussis $\Delta \mathrm{S} 3$ was identical to that obtained with B. pertussis BPSM, suggesting that the absence of the S3 subunit has no significant effect on the toxin interaction with THP. In contrast, the deletion of the S2 subunit in B. pertussis $\Delta \mathrm{S} 2$ resulted in a 35 -fold decrease of PTX binding to THP, as determined by protein quantitation of the material contained in the $3 \mathrm{M}$ urea elution peak. This indicates that the S2 subunit is involved in the recognition of THP. The residual THP binding observed with the PTX $\Delta$ S2 mutant is likely due to the high amino acid similarity displayed by the S2 and S3 subunits (Lobet et al., 1993).

\section{Glycosylation of THP is required for PTX binding}

Since carbohydrates account for approximately $30 \%$ of the THP weight (Fletcher et al., 1970), we investigated the role of the carbohydrate moiety in the THP-PTX interaction. THP was enzymically deglycosylated using $\mathrm{N}$-glycosidase $\mathrm{F}$ and $\mathrm{O}$-glycosidase, which hydrolyse $\mathrm{N}$ glycans and O-glycans, respectively. As shown in Fig. 4, $\mathrm{N}$-glycosidase F treatment reduced the apparent molecular mass of THP from approximately $95 \mathrm{kDa}$ to a doublet of approximately 70 and $66 \mathrm{kDa}$. In contrast, no apparent shift in molecular mass was observed when THP was treated with $\mathrm{O}$-glycosidase, consistent with the low level of O-glycosylation of THP (Easton et al., 2000). Since THP contains several disulfide bridges that could interfere with the enzymic deglycosylation, THP was also reduced and carboxymethylated prior to 


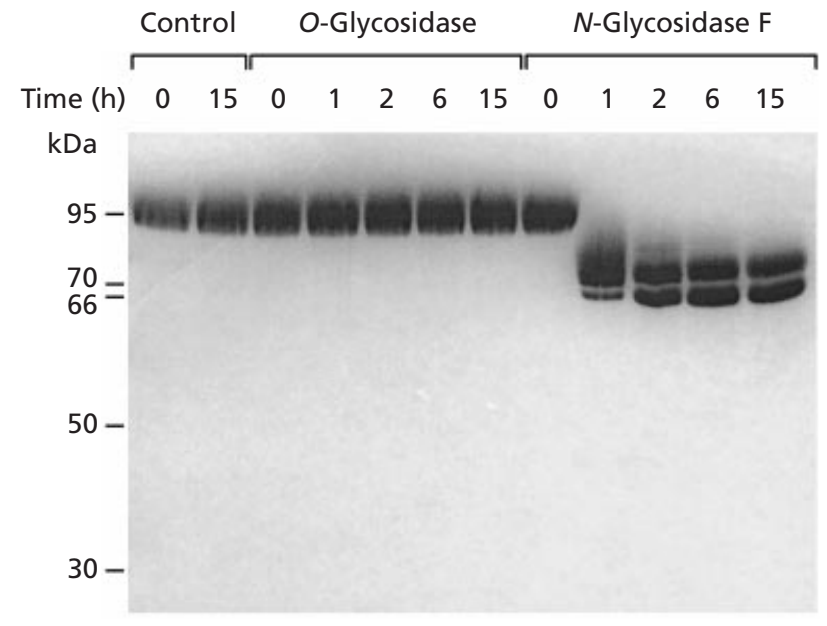

Fig. 4. SDS-PAGE analysis of deglycosylated THP. Purified THP was incubated at $37^{\circ} \mathrm{C}$ for the indicated time intervals in the presence of $\mathrm{O}$-glycosidase or $\mathrm{N}$-glycosidase $\mathrm{F}$. Control THP, incubated for 0 and $15 \mathrm{~h}$ in the absence of glycosidase, respectively, is presented in the left part of the electropherogram.

deglycosylation (data not shown). When $\mathrm{O}$ - or $\mathrm{N}$ deglycosylated THP was covalently coupled to Sepharose $4 \mathrm{~B}$ and tested for its ability to bind to PTX produced by $B$. pertussis BPSM, the toxin was no longer retained by immobilized $N$-deglycosylated THP (Fig. 3). In contrast, the PTX-binding capacity of O-deglycosylated THP was similar to that of native THP (not shown). The same results were obtained using deglycosylated reduced THP. These findings indicate that the $\mathrm{N}$-glycans borne by THP are required for PTX binding.

\section{THP-purified PTX retains its activity}

To determine whether PTX purified by THP-Sepharose chromatography retained its toxic activity, the activity of THP-purified PTX was compared in the CHO-cellclustering assay to that of PTX purified by standard methods (Sekura et al., 1983). As shown in Fig. 5, at $1 \mathrm{ng}$ purified PTX $\mathrm{ml}^{-1}$ the clustering effect induced by either method was very similar. Because the cell clustering requires binding of the holotoxin to cell surface receptors (Brennan et al., 1988), as well as the ADPribosylation of Gi proteins catalysed by the S1 subunit (Burns et al., 1987), this result indicates that the THPpurified PTX has completely retained its conformational structure and its toxic activity. When investigated for its ability to interfere with PTX activity, THP was shown to be unable to inhibit the PTX-induced clustering of $\mathrm{CHO}$ cells.

\section{THP reduces $B$. pertussis autoagglutination}

Since FHA is the major B. pertussis adhesin involved in cytoadherence (Locht et al., 1993), we wanted to know whether the THP-PTX interaction at the B. pertussis cell surface could interfere with FHA activities. We took advantage of the fact that surface-exposed FHA induces B. pertussis autoagglutination (Menozzi et al., 1994b). Freshly grown $B$. pertussis BPSM were therefore suspended in PBS or in PBS containing $100 \mu \mathrm{g}$ THP ml and observed by scanning electron microscopy. As shown in Fig. 6, THP drastically reduced the B. pertussis autoagglutination, indicating that its interaction with PTX may impede FHA activities.

\section{DISCUSSION}

Infectious diseases are multi-step processes that often start on mucosal surfaces by the attachment of the infectious micro-organism to target cells. This avoids rapid mechanical clearance. Once attached onto specific host tissues, the pathogen multiplies within an infectious focus and sometimes secretes toxins that may perturb the physiology of the host. Therefore, the microbial adhesins that mediate the initial mucosal adherence, as well as the toxins that weaken the host defences, are important virulence factors. Interference with these factors by host molecules may constitute an important mechanism for mucosal protection against infectious agents. In the lungs, the surfactant which contains mucoproteins is involved in the defence of the pulmonary mucosa by enhancing macrophage phagocytosis (a)

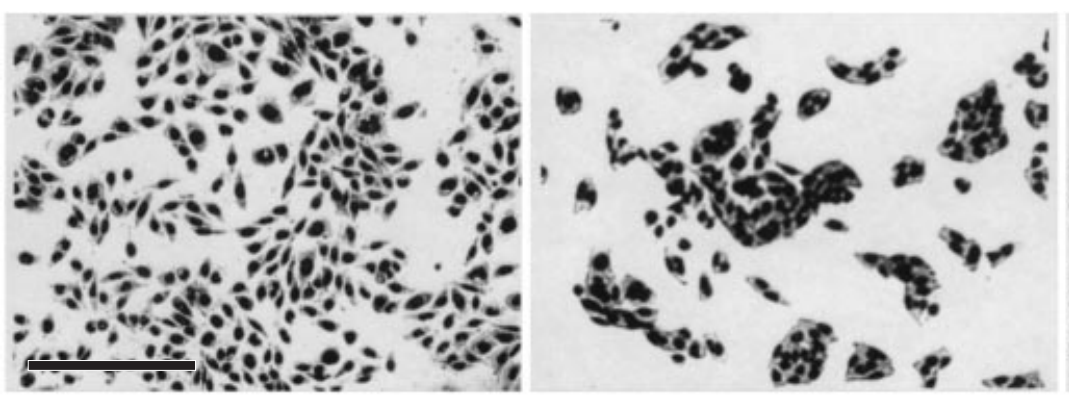

(c)

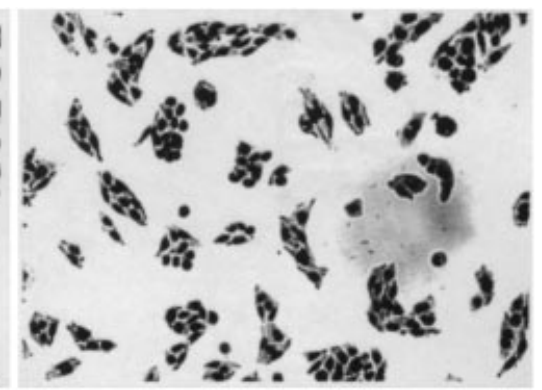

Fig. 5. $\mathrm{PTX}$-induced $\mathrm{CHO}$-cell clustering. The micrographs represent $\mathrm{CHO}$ cells cultured in the absence of $\mathrm{PTX}(\mathrm{a}), \mathrm{CHO}$ cells cultured for $12 \mathrm{~h}$ at $37^{\circ} \mathrm{C}$ in the presence of $1 \mathrm{ng} \mathrm{ml}^{-1}$ of PTX purified by the two-step standard method, including Affi-Gel Blue chromatography and fetuin-Sepharose chromatography (b), or in the presence of $1 \mathrm{ng} \mathrm{ml}^{-1}$ of PTX purified by THP-Sepharose (c). Bar, $100 \mu \mathrm{m}$. 
(a)

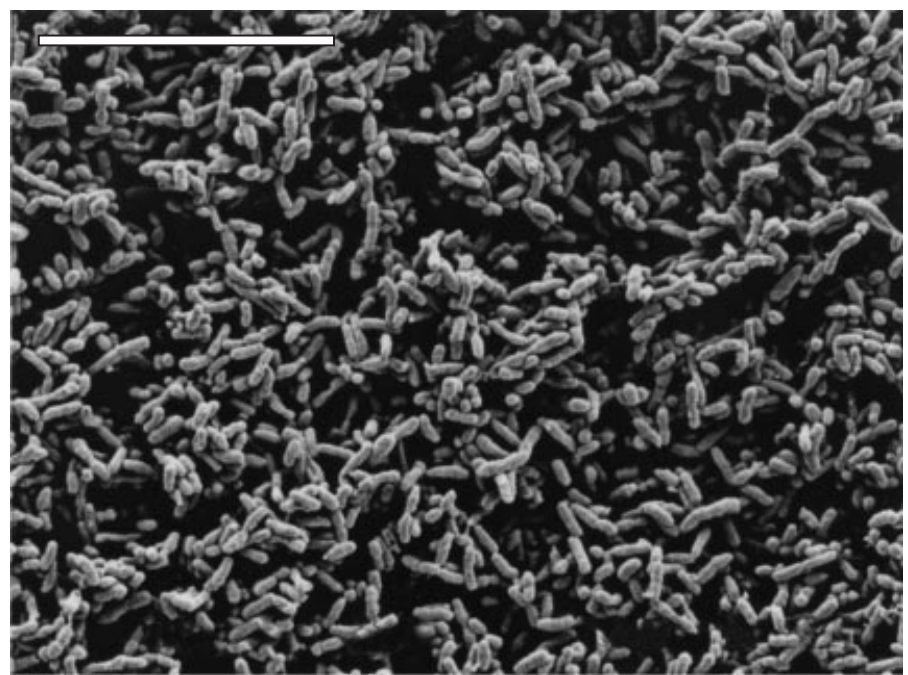

(b)

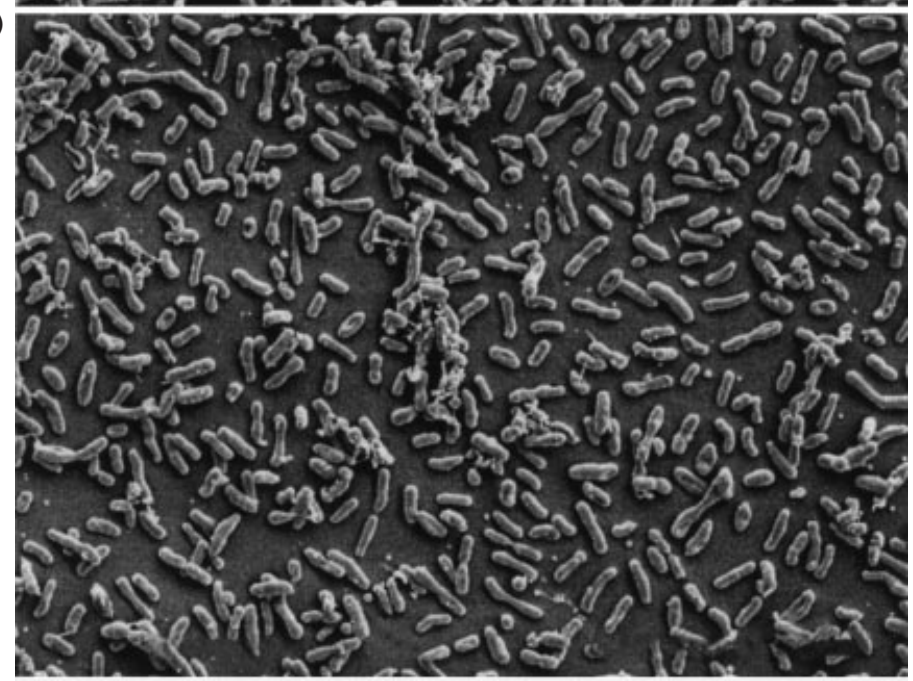

Fig. 6. Scanning electron micrographs of B. pertussis. B. pertussis BPSM grown on Bordet-Gengou agar plates was resuspended in PBS (a) or PBS containing $100 \mu \mathrm{g}$ THP ml${ }^{-1}$ (b). Bar, $10 \mu \mathrm{m}$. and by limiting microbial adherence to the underlying epithelium (Pison et al., 1994). In the urinary tract, no similar wide-spectrum defence mechanism has been described so far. The mucoprotein THP is the most abundant urinary protein and virtually covers the urothelium from the thick ascending limb of the loop of Henle to the urethra (Kumar \& Muchmore, 1990). The physiological function of THP is still unknown, but several studies have shown that it may inhibit the urothelial adherence of uropathogenic E. coli (Kuriyama \& Silverblatt, 1986; Leeker et al., 1997; Orskov et al., 1980; Pak et al., 2001). To investigate whether a similar mechanism may apply to respiratory pathogens, and since immunoreactive THP-related proteins have been detected in a number of different mucosal surfaces of various vertebrates (Howie et al., 1993), we investigated the anti-adherence properties of THP towards B. pertussis. We found that THP is able to inhibit the adherence of $B$. pertussis to both renal and pulmonary epithelial cells, suggesting that THP expresses a widespectrum anti-adherence activity. This finding also suggests that the immunoreactive THP-related proteins found on other vertebrate mucosae may play a role against infection. However, these proteins have not been characterized as yet. Surprisingly, the ligand of THP on $B$. pertussis is not one of the known adhesins, such as those described for uropathogenic E. coli, but is instead a toxin (PTX). Since the epithelial adherence of $B$. pertussis is essentially mediated by FHA and not by PTX, we postulate that the inhibitory effect observed here may be due to the capacity of THP to form large multimers (Friedmann \& Johnson, 1966), therefore allowing it to mask other surface components, like FHA. This assumption was confirmed by demonstrating that the binding of THP to B. pertussis inhibits FHAmediated autoagglutination.

The interaction of PTX with immobilized THP has been shown to be particularly strong, since it requires $3 \mathrm{M}$ urea to be completely abolished. This feature allowed us to develop a one-step chromatographic procedure to purify PTX to homogeneity from $B$. pertussis culture supernatant. This new purification procedure is cheap and may thus constitute an attractive alternative to conventional methods that generally combine two purification steps (Sekura et al., 1983). Moreover, the THP-purified PTX totally recovers its conformational structure and toxic activity, as demonstrated by the 
$\mathrm{CHO}$-cell-clustering assay. The present study has also demonstrated that the THP-PTX interaction is essentially mediated by the S2 subunit of the PTX B oligomer and that it depends on the glycosylation of THP. From enzymic deglycosylation experiments, it appears that the N-linked polysaccharides of THP are crucial for the interaction with PTX, whereas the Olinked sugars do not appear to be involved in this interaction. This finding may reflect the predominant and complex N-glycosylation content of THP (Hard et al., 1992) and its very low O-glycosylation, which is limited to short and simple chains terminated with either sialic acid or fucose (Kumar \& Muchmore, 1990).

Although the receptors for PTX on eukaryotic cells have not yet been identified, it has been shown that $\mathrm{CHO}$ cells express a $165 \mathrm{kDa}$ surface glycoprotein that is recognized by PTX or by purified B oligomer (Brennan et al., 1988). The sialic acid moiety on the N-linked oligosaccharide of this protein is an important motif of the receptor, since treatment of $\mathrm{CHO}$ cells with sialidase abolishes PTX binding. Moreover, some serum sialoglycoproteins, such as haptoglobin and fetuin, have been shown to bind to PTX via their $N$-glycosylated moieties (Witvliet et al., 1989). Similar to THP, which also bears sialylated carbohydrate chains (Hard et al., 1992), the binding of PTX to haptoglobin is mediated by the S2 subunit of the B oligomer (Francotte et al., 1989). This suggests that the same binding mechanism may mediate the interaction of PTX with THP as mediates binding of PTX with haptoglobin.

The observations reported in the present study certainly open new research perspectives for the elucidation of the physiological role of THP within the urinary tract. We show that the anti-adherence activity of THP is not limited to fimbriated uropathogenic E. coli. Moreover, we have demonstrated that THP may directly interact with a bacterial toxin, PTX. Even if this interaction has no physiological relevance, it can be taken as a model to investigate the interactions of THP with bacterial virulence factors. Because of the large repertoire of sugar motifs borne by THP, it is possible that it may also bind to toxins like the haemolysins secreted by uropathogenic bacteria, such as E. coli or Proteus mirabilis. Investigations are currently in progress in our laboratory to clarify these potential antimicrobial activities of THP.

\section{ACKNOWLEDGEMENTS}

We thank Brigitte Quatannens for the flow cytometry analyses, Pablo Bifani for his critical reading of the manuscript and Marco D. Menozzi for his help in THP purification. This research was supported by INSERM, Institut Pasteur de Lille and Région Nord-Pas de Calais. K.P. holds a fellowship from the Ministère de la Recherche et de la Technologie.

\section{REFERENCES}

Antoine, R. \& Locht, C. (1990). Roles of the disulfide bond and the carboxy-terminal region of the S1 subunit in the assembly and biosynthesis of pertussis toxin. Infect Immun 58, 1518-1526.

Antoine, R., Alonso, S., Raze, D., Coutte, L., Lesjean, S., Willery,
E., Locht, C. \& Jacob-Dubuisson, F. (2000). New virulenceactivated and virulence-repressed genes identified by systematic gene inactivation and generation of transcriptional fusions in Bordetella pertussis. J Bacteriol 182, 5902-5905.

Bachmann, S., Metzger, B., Bunnemann, M. \& Kriz, W. (1990). Tamm-Horsfall protein-mRNA is localized in the thick ascending limb of Henle's loop in rat kidney. Histochem J 94, 517-523.

Bjugn, R. \& Flood, P. R. (1988). Scanning electron microscopy of human urine and purified Tamm-Horsfall's glycoprotein. Scand J Urol Nephrol 22, 313-315.

Bordet, J. \& Gengou, O. (1906). Le microbe de la coqueluche. Ann Inst Pasteur 20, 731-741.

Brennan, M. J., David, J. L., Kenimer, J. G. \& Manclark, C. R. (1988). Lectin-like binding of pertussis toxin to a 165 -kilodalton Chinese hamster ovary cell glycoprotein. J Biol Chem 263, 4895-4899.

Burns, D. L., Kenimer, J. G. \& Manclark, C. R. (1987). Role of the A subunit of pertussis toxin in alteration of Chinese hamster ovary cell morphology. Infect Immun 55, 24-28.

Easton, R. L., Patankar, M. S., Clark, G. F., Morris, H. R. \& Dell, A. (2000). Pregnancy-associated changes in the glycosylation of Tamm-Horsfall glycoprotein. J Biol Chem 275, 21928-21938.

Fletcher, A. P., Neuberger, A. \& Ratcliffe, W. A. (1970). TammHorsfall urinary glycoprotein: the chemical composition. Biochem J 120, 417-424.

Francotte, M., Locht, C., Feron, C., Capiau, C. \& de Wilde, M. (1989). Monoclonal antibodies specific for pertussis toxin subunits and identification of the haptoglobin binding site. In Vaccines 89, pp. 243-247. Edited by R. A. Lerner, H. Ginsberg, R. M. Chanock \& R. Brown. Cold Spring Harbor, NY: Cold Spring Harbor Laboratory.

Friedmann, T. \& Johnson, P. (1966). The disaggregation of Tamm-Horsfall mucoprotein by acetic acid. Biochim Biophys Acta 121, 292-297.

Hard, K., van Zadelhoff, G., Moonen, P., Kamerling, J. P. \& Vliegenthart, J. F. G. (1992). The Asn-linked carbohydrate chains of human Tamm-Horsfall glycoprotein of one male. Eur $J$ Biochem 209, 895-915.

Hewlett, E. L., Sauer, K. T., Myers, G. A., Cowell, J. L. \& Guerrant, R. L. (1983). Induction of a novel morphological response in chinese hamster ovary cells by pertussis toxin. Infect Immun $\mathbf{4 0}$, 1198-1203.

Horton, J. K., Davies, M., Topley, N., Thomas, D. \& Williams, J. D. (1990). Activation of the inflammatory response of neutrophils by Tamm-Horsfall glycoprotein. Kidney Int 37, 717-726.

Howie, A. J., Lote, C. J., Cunningham, A. A., Zaccone, G. \& Fasulo, S. (1993). Distribution of immunoreactive Tamm-Horsfall protein in various species in the vertebrate classes. Cell Tissue Res 274, 15-19.

Hunt, J. S., McGiven, A. R., Groufsky, A., Lynn, K. L. \& Taylor, M. C. (1985). Affinity-purified antibodies of defined specificity for use in a solid-phase microplate radioimmunoassay of human Tamm-Horsfall glycoprotein in urine. Biochem J 227, 957-963.

Imaizumi, A., Suzuki, Y., Ono, S., Sato, H. \& Sato, Y. (1983). Effect of heptakis (2,6-O-dimethyl)- $\beta$-cyclodextrin on the production of pertussis toxin by Bordetella pertussis. Infect Immun 41, 11381143.

Kumar, S. \& Muchmore, A. (1990). Tamm-Horsfall proteinuromodulin (1950-1990). Kidney Int 37, 1395-1401.

Kuriyama, S. M. \& Silverblatt, F. J. (1986). Effect of TammHorsfall urinary glycoprotein on phagocytosis and killing of type I-fimbriated Escherichia coli. Infect Immun 51, 193-198. 
Laemmli, U. K. (1970). Cleavage of structural proteins during the assembly of the head of bacteriophage T4. Nature 227, 680-685.

Leeker, A., Kreft, B., Sandmann, J., Bates, J., Wasenauer, G., Müller, H., Sack, K. \& Kumar, S. (1997). Tamm-Horsfall protein inhibits binding of S- and P-fimbriated Escherichia coli to human renal tubular epithelial cells. Exp Nephrol 5, 38-46.

Lobet, Y., Feron, C., Dequesne, G., Simoen, E., Hauser, P. \& Locht, C. (1993). Site-specific alterations in the B oligomer that affect receptor-binding activities and mitogenicity of pertussis toxin. $J$ Exp Med 177, 79-89.

Locht, C., Geoffroy, M.-C. \& Renauld, G. (1992). Common accessory genes for the Bordetella pertussis filamentous hemagglutinin and fimbriae share sequence similarities with the $p a p C$ and papD gene families. EMBO J 11, 3175-3183.

Locht, C., Bertin, P., Menozzi, F. D. \& Renauld, G. (1993). The filamentous haemagglutinin, a multifaceted adhesin produced by virulent Bordetella spp. Mol Microbiol 9, 653-660.

Menozzi, F. D., Gantiez, C. \& Locht, C. (1991). Identification and purification of transferrin- and lactoferrin-binding proteins of Bordetella pertussis and Bordetella bronchiseptica. Infect Immun 59, 3982-3988.

Menozzi, F. D., Mutombo, R., Renauld, G., Gantiez, C., Hannah, J. H., Leininger, E., Brennan, M. J. \& Locht, C. (1994a). Heparininhibitable lectin activity of the filamentous hemagglutinin adhesin of Bordetella pertussis. Infect Immun 62, 769-778.

Menozzi, F. D., Boucher, P. E., Riveau, G., Gantiez, C. \& Locht, C. (1994b). Surface-associated filamentous hemagglutinin induces autoagglutination of Bordetella pertussis. Infect Immun 62, 4261-4269.

Orskov, I., Ferencz, A. \& Orskov, F. (1980). Tamm-Horsfall protein or uromucoid is the normal urinary slime that traps type I fimbriated Escherichia coli. Lancet i, 887.
Pak, J., Pu, Y., Zhang, Z.-T., Hasty, D. L. \& Wu, X.-R. (2001). Tamm-Horsfall protein binds to type 1 fimbriated Escherichia coli and prevents E. coli from binding to uroplakin $\mathrm{Ia}$ and $\mathrm{Ib}$ receptors. J Biol Chem 276, 9924-9930.

Pison, U., Max, M., Neuendank, A., Weissbach, S. \& Pietschmann, S. (1994). Host defence capacities of pulmonary surfactant: evidence for 'non-surfactant' functions of the surfactant system. Eur J Clin Invest 24, 586-599.

Sekura, R. D., Fish, F., Manclark, C. R., Meade, B. \& Zhang, Y.-L. (1983). Pertussis toxin. Affinity purification of a new ADPribosyltransferase. J Biol Chem 258, 14647-14651.

Tamm, I. \& Horsfall, F. L. (1952). A mucoprotein derived from human urine which reacts with influenza, mumps, and Newcastle disease viruses. J Exp Med 95, 71-97.

Towbin, H., Staehelin, T. \& Gordon, J. (1979). Electrophoretic transfer of proteins from polyacrylamide gels to nitrocellulose sheets: procedure and some applications. Proc Natl Acad Sci US A 76, 4350-4354.

Uhl, M. A. \& Miller, J. F. (1995). Bordetella pertussis BvgAS virulence control system. In Two-component Signal Transduction, pp. 333-349. Edited by J. Hoch \& T. Silhavy. Washington, DC: American Society for Microbiology.

Witvliet, M. H., Burns, D. L., Brennan, M. J., Poolman, J. T. \& Manclark, C. R. (1989). Binding of pertussis toxin to eucaryotic cells and glycoproteins. Infect Immun 57, 3324-3330.

Worcester, E., Nakagawa, Y., Wabner, C. L., Kumar, S. \& Coe, F. L. (1988). Crystal adsorption and growth slowing by nephrocalcin, albumin, and Tamm-Horsfall protein. Am J Physiol 255, F1197-F1205.

Received 22 August 2001; revised 16 November 2001; accepted 27 November 2001. 